\title{
The 2019 novel coronavirus (2019-nCoV) - transmission, symptoms and treatment
}

\author{
Koronawirus 2019-nCoV - transmisja zakażenia, objawy i leczenie
}

Department of Paediatrics, Paediatric Nephrology and Allergology, Central Clinical Hospital of the Ministry of Defence, Military Institute of Medicine, Warsaw, Poland

Correspondence: Agata Wawrzyniak, Department of Paediatrics, Paediatric Nephrology and Allergology, Central Clinical Hospital of the Ministry of Defence, Military Institute of Medicine,

Szaserów 128, 04-141 Warsaw, Poland, e-mail: awawrzyniak@wim.mil.pl

Abstract For years, coronaviruses have been regarded as benign pathogens responsible for mild respiratory symptoms resolving spontaneously within a few days. However, the emergence of new, highly infectious species increased interest in these pathogens. In November 2002, an epidemic caused by a previously unknown, highly infectious coronavirus species (SARS) broke out in one of the Chinese provinces. Ten years later, cases of a new respiratory disease caused by MERS coronavirus were reported. Both SARS and MERS are classified as zoonotic viruses, which may cause infections in humans and animals. Bats are their natural reservoir hosts. These viruses had to cross the species border twice, i.e. first transmission from bats to other mammals (intermediate hosts), followed by transmission from these mammals to humans, to become pathogenic to humans. Human-to human transmission of SARS and MERS occurs through close contact (droplets, direct contact). High resistance to environmental factors and the ability to survive in an aerosol are important species-specific pathogenicityrelated features of coronaviruses. The aim of this paper was to present the characteristics of the new coronavirus known as 2019-nCoV, which emerged in the human population in 2019. We discussed the course of transmission and epidemic outbreak, the symptoms and immune response to infection as well as treatment options and prognosis.

Keywords: epidemic, pandemic, coronavirus, zoonosis, acute respiratory failure

Przez lata koronawirusy traktowane były jako łagodne patogeny, wywołujące nieznacznie nasilone objawy ze strony dróg oddechowych, ustępujące w ciągu kilku dni. Dopiero pojawienie się nowych, wysoce zakaźnych gatunków spowodowało wzrost zainteresowania tymi patogenami. W listopadzie 2002 roku w jednej z chińskich prowincji wybuchła epidemia wywołana przez nieznany wcześniej, wysoce zakaźny gatunek koronawirusa - SARS. Dziesięć lat od epidemii SARS ogłoszono przypadki nowej choroby układu oddechowego, wywołanej przez koronawirusa MERS. Zarówno SARS, jak i MERS są wirusami zoonotycznymi, mogącymi wywoływać zakażenia zarówno u ludzi, jak i u zwierząt. Ich naturalnym rezerwuarem są nietoperze. Aby wirusy te mogły być patogenne dla ludzi, musi dwukrotnie dojść do tak zwanego przełamania gatunkowego najpierw pomiędzy nietoperzami a innymi ssakami (żywicielami pośrednimi), następnie zaś między tymi ssakami a człowiekiem. Do transmisji zakażenia wirusami SARS i MERS między ludźmi dochodzi w wyniku bliskiego kontaktu (droga kropelkowa, kontakt bezpośredni). Istotnymi cechami gatunkowymi koronawirusów, związanymi z ich patogennością, są wysoka odporność na warunki środowiskowe oraz zdolność przetrwania w postaci aerozolu. Celem niniejszej pracy jest przedstawienie charakterystyki nowego koronawirusa, który pojawił się w populacji ludzi w grudniu 2019 roku - 2019-nCoV. Omówiono przebieg transmisji zakażenia i wybuchu epidemii, objawy i odpowiedź immunologiczną na zakażenie, możliwości leczenia oraz rokowanie.

Słowa kluczowe: epidemia, pandemia, koronawirusy, zoonozy, ostra niewydolność oddechowa 


\section{INTRODUCTION}

$\mathrm{C}$ oronaviruses belong to RNA viruses with the largest size of virion and genome. The name coronavirus derives from the Latin word corona, referring to their envelop, which appears under an electron microscope as a crown-like structure with small projections.

For years, coronaviruses have been considered to be benign pathogens responsible for mild respiratory symptoms resolving spontaneously within a few days. However, the emergence of new, highly infectious species increased interest in these pathogens. In November 2002, an epidemic caused by a previously unknown, highly infectious coronavirus species (SARS) broke out in one of the Chinese provinces. The name of the virus refers to the disease it causes, i.e. severe acute respiratory syndrome. The infection causes damage to the pulmonary tissue and initiation of excess immune response. High mortality and viral infectiousness led to a global pandemic. During one season, the virus spread to 37 different countries, causing 8,273 cases of infection, including 775 deaths $^{(1,2)}$. In July 2003, the World Health Organization (WHO) confirmed that SARS was eradicated. Its sudden elimination was explained by the use of effective means to prevent pathogen transmission.

In 2012, ten years after SARS epidemic, cases of a new respiratory disease caused by MERS coronavirus, now known as the Middle East respiratory syndrome, were reported. Since human-to-human transmission of MERS requires long-term close contact with an infected person, global epidemics was avoided. To date, 2,030 MERS cases in 27 countries, including 748 deaths were reported ${ }^{(3)}$.

Both SARS and MERS are classified as zoonotic viruses, which may cause infections in humans and animals. Bats are their natural reservoir hosts. These viruses had to cross the species border twice, i.e. first transmission from bats to other mammals (intermediate hosts), followed by transmission from these mammals to humans, to become pathogenic to humans. Raccoon dogs and palm civets are intermediate hosts for SARS, whereas camels are intermediate hosts for MERS ${ }^{(4,5)}$.

SARS and MERS are transmitted from human to human via close contact (droplets, direct contact). High resistance to environmental factors and the ability to survive in an aerosol are important species-specific pathogenicity-related features of coronaviruses. Therefore, they are able to spread through e.g. a ventilation system. Transmission through direct contact (contaminated objects) via the faecal-oral route is also important ${ }^{(6,7)}$.

Alongside rhinoviruses, adenoviruses or influenza viruses, human coronaviruses are reported as one of the most common causes of respiratory infections. In the vast majority of cases, they induce mild symptoms resolving spontaneously within a few days ${ }^{(8)}$. However, SARS and MERS, which could cause severe pneumonia leading to respiratory failure and even death, turned out to be an exception ${ }^{(9)}$. The incubation period is similar for these pandemic viruses, though slightly longer for MERS (2-15 days vs. 2-14 days for SARS). The symptoms of infection are similar and usually include fever, muscle pain, diarrhoea and vomiting. However, there are some differences in the clinical course of infections induced by these pathogens. SARS causes pneumonia, which leads to acute respiratory distress syndrome (ARDS) requiring mechanical ventilation. Respiratory tract infections caused by MERS, on the other hand, may be asymptomatic, mild or they may lead to $\operatorname{ARDS}^{(10,11)}$.

The aim of this paper was to present the characteristics of the new coronavirus known as 2019-nCoV, which emerged in the human population in 2019. We discussed the course of transmission and epidemic outbreak, the symptoms and immune response to infection as well as treatment options and prognosis.

\section{THE DEVELOPMENT OF 2019-nCoV EPIDEMIC}

In December 29, 2019, four cases of pneumonia of unknown aetiology were reported by several local healthcare facilities in Wuhan (China). Two days later, the Wuhan Municipal Health Commission published first official statement on the cases of infection. All cases were epidemiologically linked to a local seafood market, which suggested a zoonotic transmission of the infection ${ }^{(12)}$. On December 31, 2019, the Chinese Center for Disease Control and Prevention (China CDC) dispatched a rapid response team to conduct an epidemiologic and aetiological investigation on the unknown aetiological factor ${ }^{(13)}$. The fish market was closed and disinfected the following day, and on January 9, 2020 the China CDC announced in the "The Wall Street Journal" that a new coronavirus $(2019-n \mathrm{CoV})$ was identified ${ }^{(14)}$. The virus was isolated from the first patient and subsequently verified in 16 additional patients ${ }^{(15)}$.

First sequences of the genome were reported within the next 2 days (January 10-11, 2020)(16), and starting from January 13 , authorities of other countries began reporting cases of 2019-nCoV on their territory, with first reports in Thailand, Japan and South Korea ${ }^{(17)}$. At the same time, the first deaths due to pneumonia caused by the virus were reported $^{(17)}$. Cases of disease spread to healthcare workers and family members who had no direct contact with the animal source indicated possible human-to-human transmission of the virus ${ }^{(17,18)}$. Fig. 1 shows a flow chart for the 2019-nCoV outbreak.

\section{IMMUNE RESPONSE TO INFECTION}

The pathophysiology underlying the extremely high pathogenicity of coronaviruses is not fully understood ${ }^{(9)}$. However, it is believed that not only viral factors, but also the host's immune response is important. 


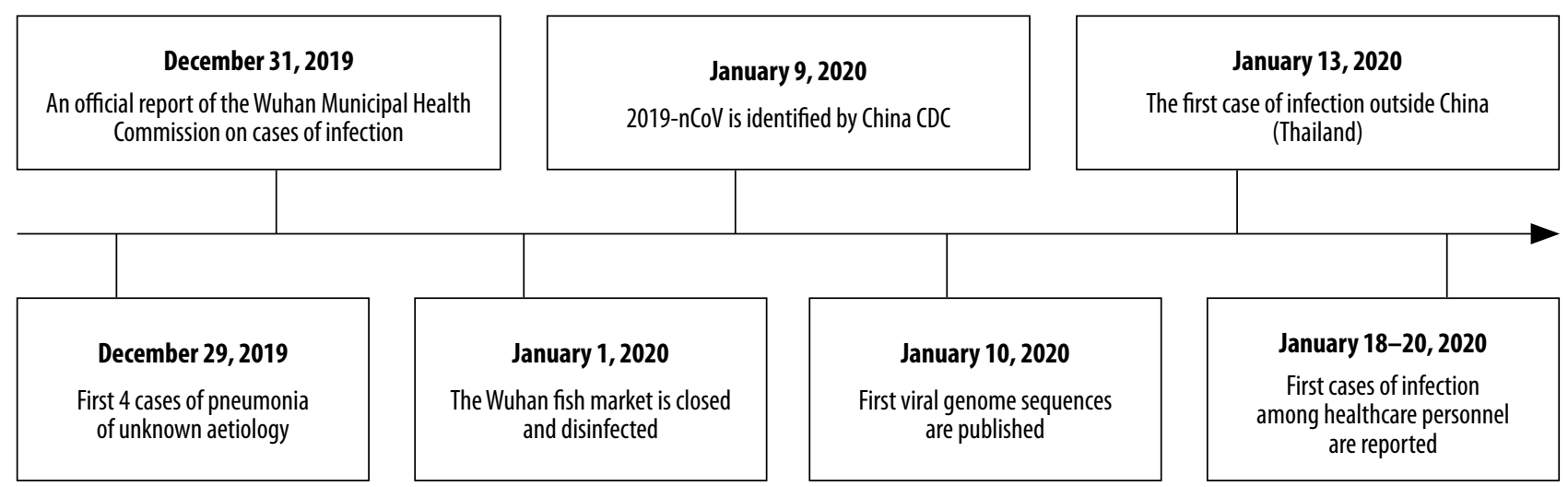

Fig. 1. A flow chart for the 2019-nCoV outbreak

Increased serum levels of pro-inflammatory cytokines, such as interleukins (IL-1B, IL-6, IL-12, IL-17), interferon gamma (IFN- $\gamma$ ) and tumour necrosis factor a (TNF- $\alpha$ ), are found in patients with SARS and MERS. Although they can activate helper T cells (Th1), which play a key role in removing the virus from the infected cells, they simultaneously induce pulmonary tissue destruction, with the extent of damage proportional to their levels. A similar correlation was observed in 2019-nCoV-infected patients admitted to hospital in Wuhan. Patients hospitalised in the intensive care unit due to complications presented with higher levels of cytokines [IL-1B, IFN- $\gamma$, interferon gamma-induced protein 10 (IP-10) and monocyte chemoattractant protein 1 (MCP1) in particular] compared to patients receiving conservative treatment ${ }^{(9)}$.

Pulmonary tissue oedema and inflammatory cell infiltration occur during infection. This leads to exfoliation of alveolar epithelial cells and damage to alveolar septa. The pulmonary vascular endothelium is also damaged ${ }^{(19)}$. These changes may induce both relatively mild functional disorders and ARDS leading to death.

\section{SYMPTOMS AND CLINICAL COURSE}

The incubation period of $2019-\mathrm{nCoV}$ is $4-7$ days (mean: 5 days) ${ }^{(18,20)}$, and the infectivity period is $5-19$ days (mean: 7 days), according to current research findings ${ }^{(18)}$. The latest, unpublished data indicate that the incubation period may be up to 24 days in rare cases.

The most common initial symptoms include fever (98\%), dry cough $(76 \%)$, muscle pain and general asthenia. Headache, haemoptysis and diarrhoea are less common. The majority of infected patients develop dyspnoea. It typically occurs within 2 days of hospital admission ${ }^{(9)}$.

Huang et al. and Chan et al. found that the most common laboratory abnormalities in patients hospitalised due to 2019-nCoV infection included leukopenia with lymphopenia, thrombocytopenia, elevated C-reactive protein (CRP) and low procalcitonin (PCT). Chest computed tomography findings included ground glass opacities corresponding to pulmonary inflammatory lesions, mostly peripheral. Lobar and subsegmental consolidations were less common ${ }^{(9,18)}$.

According to current data, all 2019-nCoV-infected patients develop pneumonia ${ }^{(9)}$. However, the severity of the disease varies from relatively mild conservativelytreated cases to respiratory failure requiring hospitalisation in an intensive care unit ${ }^{(17)}$. The most common complications include ARDS (29\%), which usually develops at day 2-3 of hospital stay, viraemia (15\%), acute myocardial injury (12\%) and secondary bacterial infection $(10 \%)$. On average, mechanical ventilation due to respiratory failure is needed in one in ten hospitalised patients ${ }^{(9)}$.

Mean time between symptom onset and hospitalisation is 6-12 days, depending on the source ${ }^{(9,20)}$. Although patients seek medical help relatively early after symptom onset (about 2 days), the delay in hospitalisation is much longer. This indicates difficulties in the diagnosis and isolation of these patients at early stages of the disease $\mathrm{e}^{(20)}$.

The course of infection depends mainly on patient's age. Shorter incubation period, more severe clinical and radiological symptoms as well as higher inflammatory markers are observed in older patients. It can be assumed at this stage of knowledge that children are less susceptible to 2019-nCoV infection. Infected children present with milder symptoms or are asymptomatic. However, both these hypotheses need to be confirmed in further clinical observation $^{(18,20)}$.

\section{TREATMENT}

Currently, there is no effective treatment or vaccine against coronaviruses $^{(21,22)}$. The treatment of 2019-nCoV-infected patients primarily involves empirical use of oseltamivir, antibiotics and corticosteroids, as well as adjunctive symptomatic therapy ${ }^{(9)}$.

Oseltamivir should be administered as early as possible. It is used due to its proven efficacy against MERS. 
Hoverer, there is currently no evidence that a similar effect will be observed for the new coronavirus ${ }^{(22)}$.

Oral and intravenous antibiotic therapy is used mainly to prevent bacterial superinfection.

Corticosteroids are used in patients with severe pneumonia to reduce the destructive effects of excess immune response on the pulmonary tissue ${ }^{(9)}$. Their use should be considered individually, based on the risk/ benefit ratio. There are reports on the negative effects of corticosteroid therapy on the course of viral infection. It was shown that corticosteroid therapy failed to reduce mortality and delayed viral clearance in patients with SARS and MERS ${ }^{(23,24)}$. Therefore, according to the current WHO guidelines, corticosteroid therapy should not be routinely used in patients with SARS and MERS $^{(25)}$. However, evidence showing that a similar effect may be seen in 2019-nCoV-induced pneumonia is needed.

The 2020 guidelines of the National Health Commission of the People's Republic of China recommend the use of IFN- $\alpha$ and lopinavir/ritonavir as first-choice antivirals ${ }^{(26)}$. Particularly, lopinavir/ritonavir combination therapy (protease inhibitors used in the treatment of human immunodeficiency virus - HIV) shows proven efficacy in reducing the risk of acute respiratory distress or mortality in SARS infection $^{(27)}$.

Adjuvant symptomatic treatment, such as e.g. oxygen therapy, mechanical ventilation as well as cardiac care and haemodialysis in the case of secondary cardiac or renal damage, also play a very important role in the management of patients with 2019-nCoV-induced pneumonia.

There has been ongoing research on causative treatments for coronavirus infections since SARS epidemic. Remdesivir, a novel nucleotide analogue originally developed for the treatment of diseases caused by Ebola and Marburg viruses, is the best potential treatment for 2019-nCoV.
Animal experiments using MERS showed that the drug may effectively reduce viral titres and pulmonary tissue damage. Remdesivir has completed phase III clinical trials for the treatment of Ebola haemorrhagic fever, during which complete data on its pharmacokinetics was collected and safety for humans was confirmed ${ }^{(28)}$. However, the efficacy and safety of remdesivir in 2019-nCoV-infected patients needs to be confirmed in further clinical trials ${ }^{(22)}$.

\section{PROGNOSIS}

The majority of patients recover and eliminate the virus, as confirmed by studies in the Wuhan hospital, where $68 \%$ of hospitalised patients were discharged home after molecular confirmation of viral clearance in respiratory samples ${ }^{(9)}$. Recovery was also reported for the vast majority of other described cases ${ }^{(18-20)}$.

Current data indicate that mortality is significantly lower (2.84\%) compared to SARS $(9.6 \%)$ and MERS $(34.4 \%)^{(21)}$. Furthermore, mortality is most often reported in elderly individuals (median: 75 years), patients with comorbidities or a history of surgical treatment. The mean time between disease onset and death is 14 days (6-41 days), but it may be shorter in patients aged $\geq 70$ years $^{(21)}$.

\section{CONCLUSIONS}

The vast majority of coronavirus infections are mild. However, some species may cause pandemic infections posing a threat to human health and life. Rapid diagnosis and appropriate treatment are important to reduce the spread of the virus in the population.

\section{Conflict of interest}

The authors do not report any financial or personal connections with other persons or organizations, which might negatively affect the contents of this publication and/or claim authorship rights to this publication. 


\section{References}

1. Rota P, Oberste M, Monroe SS et al.: Characterization of a novel coronavirus associated with severe acute respiratory syndrome. Science 2003; 300: 1394-1399.

2. Drosten C, Günther S, Preiser W et al.: Identification of a novel coronavirus in patients with severe acute respiratory syndrome. N Engl J Med 2003; 348: 1967-1976.

3. Pancer KW: Pandemiczne koronawirusy człowieka - charakterystyka oraz porównanie wybranych właściwości HCoV-SARS i HCoV-MERS. Post Mikrobiol 2018; 57: 22-32.

4. Ding Y, He L, Zhang Q et al.: Organ distribution of severe acute respiratory syndrome (SARS) associated coronavirus (SARS$\mathrm{CoV}$ ) in SARS patients: implications for pathogenesis and virus transmission pathways. J Pathol 2004; 203: 622-630.

5. Lui PY, Wong LYR, Fung CL et al.: Middle East respiratory syndrome coronavirus $\mathrm{M}$ protein suppresses type I interferon expression through the inhibition of TBK1-dependent phosphorylation of IRF3. Emerg Microbes Infect 2016; 5: e39.

6. van Doremalen N, Bushmaker T, Munster VJ: Stability of Middle East respiratory syndrome coronavirus (MERS-CoV) under different environmental conditions. Euro Surveill 2013; 18. pii: 20590.

7. Wong LY, Lui PY, Jin DY: A molecular arms race between host innate antiviral response and emerging human coronaviruses. Virol Sin 2016; 31: 12-23.

8. Pyrć K: Ludzkie koronawirusy. Post Nauk Med 2015; 28 (4B): 48-54.

9. Huang C, Wang Y, Li X et al.: Clinical features of patients infected with 2019 novel coronavirus in Wuhan, China. Lancet 2020 pii: S0140-6736(20)30183-5. DOI: 10.1016/S01406736(20)30183-5.

10. Gralinski LE, Bankhead A $3^{\text {rd }}$, Jeng S et al.: Mechanisms of severe acute respiratory syndrome coronavirus-induced acute lung injury. mBio 2013; 4. pii: e00271-13. DOI: 10.1128/mBio.00271-13.

11. Drosten C, Seilmaier M, Corman VM et al.: Clinical features and virological analysis of a case of Middle East respiratory syndrome coronavirus infection. Lancet Infect Dis 2013; 13: 745-751.

12. Report of clustering pneumonia of unknown etiology in Wuhan City. Wuhan Municipal Health Commission, 2019. Available from: http://wjw.wuhan.gov.cn/front/web/showDetail/2019123108989 [cited: 6 February 2020].

13. Zhu N, Zhang D, Wang $\mathrm{W}$ et al.; China Novel Coronavirus Investigating and Research Team: A novel coronavirus from patients with pneumonia in China, 2019. N Engl J Med 2020. DOI: 10.1056/NEJMoa2001017.

14. Khan N: New virus discovered by Chinese scientists investigating pneumonia outbreak. The Wall Street Journal, 2020. Available from: https://www.wsj.com/articles/new-virus-discoveredby-chinese-scientists-investigating-pneumonia-outbreak-11578485668 [cited: 6 February 2020].
15. World Health Organization: WHO Statement Regarding Cluster of Pneumonia Cases in Wuhan, China. Available from: https:// www.who.int/china/news/detail/09-01-2020-who-statementregarding-cluster-of-pneumonia-cases-in-wuhan-china [cited: 6 February 2020].

16. Virological.org: Novel 2019 coronavirus genome. Available online: http://virological.org/t/novel-2019-coronavirusgenome/319 [cited: 19 January 2020].

17. Gralinski LE, Menachery VD: Return of the coronavirus: 2019nCoV. Viruses 2020; 12. pii: E135. DOI: 10.3390/v12020135.

18. Chan JF, Juan S, Kok KH et al.: A familial cluster of pneumonia associated with the 2019 novel coronavirus indicating person-toperson transmission: a study of a family cluste. Lancet 2020. pii: S0140-6736(20)30154-9. DOI: 10.1016/S0140-6736(20)30154-9.

19. Li G, Fan Y, Lai $Y$ et al.: Coronavirus infections and immune responses. J Med Virol 2020. DOI: 10.1002/jmv.25685.

20. Li Q, Guan X, Wu P et al.: Early transmission dynamics in Wuhan, China, of novel coronavirus-infected pneumonia. N Engl J Med 2020. DOI: 10.1056/NEJMoa2001316.

21. Wang W, Tang J, Wei F: Updated understanding of the outbreak of 2019 novel coronavirus (2019-nCoV) in Wuhan, China. J Med Virol 2020. DOI: 10.1002/jmv.25689.

22. Lu H: Drug treatment options for the 2019-new coronavirus (2019-nCoV). Biosci Trends 2020. DOI: 10.5582/bst.2020.01020.

23. Stockman LJ, Bellamy R, Garner P: SARS: systematic review of treatment effects. PLoS Med 2006; 3: e343.

24. Arabi YM, Mandourah Y, Al-Hameed F et al.; Saudi Critical Care Trial Group: Corticosteroid therapy for critically ill patients with Middle East respiratory syndrome. Am J Respir Crit Care Med 2018; 197: 757-767.

25. World Health Organization: Clinical management of severe acute respiratory infection when novel coronavirus $(\mathrm{nCoV})$ infection is suspected. Jan 11, 2020. Available from: https://www. who.int/publications-detail/clinical-management-of-severeacute-respiratory-infection-when-novel-coronavirus-(ncov)-infection-is-suspected [cited: 23 January 2020].

26. National Health Commission of the People's Republic of China: Notice on printing and distributing the diagnosis and treatment plan of pneumonia with new coronavirus infection (trial version 3). Available from: http://www.nhc.gov.cn/yzygj/s7653p/202001/ f492c9153ea9437bb587ce2ffcbeelfa.shtml [cited: 23 January 2020].

27. Chu CM, Cheng VC, Hung IF et al.; HKU/UCH SARS Study Group: Role of lopinavir/ritonavir in the treatment of SARS: initial virological and clinical findings. Thorax 2004; 59: 252-256.

28. Agostini ML, Andres EL, Sims AC et al.: Coronavirus susceptibility to the antiviral remdesivir (GS-5734) is mediated by the viral polymerase and the proofreading exoribonuclease. mBio 2018; 9. pii: e00221-18. DOI: 10.1128/mBio.00221-18.

29. Phan LT, Nguyen TV, Luong QC et al.: Importation and humanto-human transmission of a novel coronavirus in Vietnam. N Engl J Med 2020. DOI: 10.1056/NEJMc2001272. 